\title{
TYPOLOGY OF STUDENTS ACCORDING TO THEIR LEVEL OF INTEREST IN THE EDUCATION THROUGH E-LEARNING: IS E-LEARNING SUITABLE FOR EVERYONE?
}

\author{
Milan KLENENT - Miroslav CHRÁSKA
}

\begin{abstract}
E-learning is an integral part of modern tertiary education, not only in combined study modes, but increasingly also within the framework of full-time ones. Along with its deployment on a large scale, new problems have arisen that shall be treated, investigated and solved. The present article reflects the attitudes of university students to e-learning implemented within the course of their studies, and submits partial results of an investigation, which took place in 2012. The aim of the latter was to determine students' opinions and preferences with respect to the form, the arrangement, and the individual instruments or elements of e-learning through a research questionnaire.
\end{abstract}

Key words: cluster analysis, distance learning, e-learning, typology of university students.

\section{TYPOLOGIE STUDENTŮ DLE ZÁJMU O VZDĚLÁVÁNÍ REALIZOVANÉ FORMOU E-LEARNINGU ANEB: JE E-LEARNING VHODNÝ PRO KAŽDÉHO?}

Resumé: E-learning je integrální součástí moderního vysokoškolského vzdělávání, a to nejen $\mathrm{v}$ př́padě kombinovaných, ale ve stále větší míře i prezenčních studijních programů. $\mathrm{V}$ souvislosti $\mathrm{s}$ jeho nasazením v širším měřítku vyplývá řada problémů, které je žádoucí zkoumat a řešit. Článek reflektuje postoje studentů vysokých škol $\mathrm{k}$ e-learningu $\mathrm{v}$ rámci realizace jejich studia a představuje dílčí výsledky výzkumného šetření, které probíhalo v roce 2012. Cílem bylo zjistit preference a názory studentů na formu, uspořádání a jednotlivé nástroje či prvky e-learningu pomocí výzkumného dotazníku.

Kličová slova: shluková analýza, distanční vzdělávání, e-learning, typologie studentů VŚ.

\section{1 Úvod}

Jelikož je pojem e-learning vnímán a definován různorodě, provedeme jeho definování tak, aby byl v souvislosti s touto studií chápán jednoznačně. V anglosaských zemích se pro aktivity spojené s podporou výuky pomocí ICT (e-support) používá namísto pojmu e-learning (Lowenthal, Wilson, 2009) relativně ustálených pojmů Computer-Based Training (CBT), Internet-Based Training (IBT) nebo WebBased Training (WBT) (Zounek, 2009). V souladu se všeobecným náhledem chápeme e-learning jako takový typ učení, při němž získávání a používání znalostí je distribuováno a usnadňováno elektronickými zařízeními (Průcha, J. a kol., 2009).

E-learning v tomto pojetí zahrnuje nejen řadu nástrojů, které slouží pro prezentaci, transfer vzdělávacího obsahu a řízení studia, ale také celé spektrum komunikačních kanálů. Využití nástrojů umožňuje Learning Management System (LMS), který je nezbytným předpokladem pro skutečně efektivní proces vzdělávání s využitím e-learningu. LMS tedy reprezentuje virtuální „učebni'“ prostředí, ve kterém se nacházejí studijní opory, zkušební testy, studijní instrukce, cvičební plány nebo diskusní fóra (Mauthe, Thomas, 2004). Základními nástroji realizace e-learningového vzdělávání jsou mimo LMS také vhodně strukturované a didakticky uzpůsobené vzdělávací texty, zkráceně označované elektronické studijní opory nebo jen studijní opory (srov. Paulsen, 2003; Šedá, 2010; Kopecký, 2006). Elektronické studijní opory mají svá specifika, nebot' jsou určeny pro formu studia, která je charakteristická především vyšší mírou samostatnosti a individuálnosti (Bates, Poole, 2003).

\section{Charakteristika výzkumného šetření}

Bylo realizováno výzkumné šetření, jehož výsledky byly zpracovány za využití vícerozměrných statistických metod shlukové a faktorové analýzy a kterého se zúčastnilo 1625 respondentů. $\mathrm{Na}$ základě provedeného výzkumného šetření jsme prokazovali, že existuje 
6 základních hodnotících oblastí, z nichž každá obsahuje pět až dvanáct nejdůležitějších hodnotících kritérií, která jsou nezbytná pro relevantní posouzení vlastností elektronických studijních opor $\mathrm{v}$ dané oblasti hodnocení. Optimalizovaný systém hodnoticích kritérií, byl rozčleněn do šesti základních oblastí.

Jednotlivé oblasti optimalizovaného systému hodnocení vzdělávacích materiálů určených pro distanční vzdělávání a e-learning jsou naplněny celkem 42 hodnotícími kritérii vzniklými na základě teoretické analýzy, které vymezují jednotlivé vlastnosti, chování, fungování, obsah či strukturu posuzované součásti vzdělávacího materiálu. Na základě těchto hodnotících kritérií byl sestaven výzkumný dotazník, který operoval se dvěma typy dotazníkových otázek. Prvním typem otázek byly polynomické stupnicové (Horák, Chráska, 1983, s. 96). Pomocí nich respondenti posuzovali důležitost jednotlivých evaluačních kritérií podle předem stanované škály. Tato hodnotící škála obsahovala 7 stupňů, kde číslo 1 znamenalo, že evaluační kritérium není pro respondenta vůbec důležité, naopak číslo 7 znamenalo, že toto kritérium je pro respondenta velmi důležité. Druhým typem byly otázky dichotomické, které byly použity pro zjišstování základních charakteristik respondentů, a tudíž byly zpravidla nabízeny pouze dvě alternativy odpovědí ano - ne (Horák, Chráska, 1983, s. 96).

Vytvořený dotazník byl distribuován mezi studenty osmi vysokoškolských institucí po dobu 4 měsíců prostřednictvím elektronického databázového systému, který byl zakomponován do LMS systému Unifor jednotlivých škol. Do výzkumného šetření se tak mohli zapojit všichni studenti, kteři v rámci svého studia na 7 fakultách vysokých škol a jedné akademii realizovali některou $\mathrm{z}$ částí studia distanční formou s využitím e-learningu. Do výzkumného šetření byly zapojeny tyto vysokoškolské instituce: Cyrilometodějská teologická fakulta Univerzity Palackého v Olomouci (CMTF UP); Fakulta ekonomická Západočeské Univerzity v Plzni (FE ZČU); Fakulta tělesné kultury Univerzity Palackého v Olomouci (FTK UP); Filozofická fakulta Univerzity Palackého v Olomouci (FF UP); Justiční Akademie v Kroměříži (JA Kroměříž); Pedagogická fakulta Univerzity Palackého v Olomouci (PdF UP); Pedagogická fakulta Univerzita Hradec Králové (PdF UHK); Právnická fakulta Univerzity Palackého v Olomouci (PF UP)
V rámci prokazování výše uvedeného výzkumného předpokladu bylo nutné také podrobně analyzovat skupinu respondentů a zaměrit se tak je vymezení typologie jednotlivých skupin respondenti̊. Zvláštní zřetel byl kladen na ty skupiny respondentů, které by mohly negativním způsobem ovlivnit výsledky výzkumného šetření. Použité metody, postup a výsledky této dílčí části výzkumného šetření popisuje další text článku.

\section{Popis použité výzkumné metody}

Kromě neparametrických testů pro závislé výběry, které jsou určeny pro ordinální proměnné a při nichž je nutno zadávat podobnost proměnných, které chceme zjištovat, existují metody zaměřené na shlukování. Protože je současně zjištována rozdílnost skupin proměnných, jsou v současné literatuře (zejména $\mathrm{v}$ souvislosti $\mathrm{s}$ termínem ,data mining") označovány tyto úlohy jako segmentace (Řezanková, 2010, s. 188).

Shlukovou analýzu můžeme použít $\mathrm{v}$ př́ípadech, kdy jsou proměnné stejného typu. Speciální míry vzdálenosti (resp. podobnosti) existují pro diskrétní číselné proměnné a pro proměnné binární (Koschin, 1992, s. 156). Při hierarchické shlukové analýze se počítá matice vzdálenosti, resp. podobnosti, nejprve pro všechny dvojice proměnných a poté se kombinují vzdálenosti jednak mezi jednotlivými proměnnými a také mezi vzniklými shluky proměnných. Uvedený postup je použitelný jak pro zjišstování podobnosti proměnných, tak pro zjišt'ování podobnosti objektů.

Výše uvedených skutečností bylo možné využít př̀ analýze získaného výzkumného vzorku, přičemž jej bylo možné rozdělit do skupin podle podobnosti hodnocení evaluačních kritérií. Na základě tohoto rozdělení bylo možné identifikovat jednotlivé skupiny respondentů, a minimalizovat tak vliv netypických skupin na průběh a výsledky výzkumu, který bývá také označovaný jako „čištění dat" (Ježek, Vaculík, Wortner, 2006, s. 9). Využití tohoto postupu bylo pro zajištění věrohodnosti výsledků celého výzkumného šetření nezbytné, a proto je možné shlukovou analýzu označit za hlavní metodu, použitou při vyhodnocení získaných dat.

\section{Popis výzkumného vzorku}

Výzkumný vzorek analýzy tvořilo celkem 1625 studentů osmi vysokoškolských institucí, kteří absolvovali výuku $\mathrm{v}$ rámci 
prezenčních i kombinovaných forem studia, prostřednictvím LMS Unifor za využití vzdělávacích materiálů určených pro distanční vzdělávání a e-learning (takzvaných elektronických studijních opor). Výzkumný vzorek odpovídal celkové struktuře studentů realizujících celé studium či část studia distanční formou, nebot' popsané šetření bylo zakomponováno do běžné výuky. Strukturu výzkumného vzorku uvádí následující tabulka číslo1.

\begin{tabular}{|c|c|c|c|c|c|c|c|c|}
\hline \multicolumn{9}{|c|}{$\begin{array}{l}\text { Struktura výzkumného vzorku } \\
n=6243\end{array}$} \\
\hline \multirow[b]{2}{*}{$\begin{array}{l}\text { Vysokoškolská } \\
\text { instituce }\end{array}$} & \multicolumn{4}{|c|}{ respondenti } & \multicolumn{4}{|c|}{ věková struktura } \\
\hline & \begin{tabular}{|c|} 
oslo \\
vení \\
studenti
\end{tabular} & \begin{tabular}{|c|} 
zapo \\
jení \\
studenti
\end{tabular} & $\begin{array}{r}\mathrm{z} \\
\text { toho } \\
\text { ženy } \\
\end{array}$ & $\begin{array}{r}\mathrm{Z} \\
\text { toho } \\
\text { muži }\end{array}$ & $\begin{array}{l}15- \\
30 \text { let }\end{array}$ & $\begin{aligned} & 30-- \\
& 45 \text { let }\end{aligned}$ & $\begin{array}{r}45- \\
60 \text { let }\end{array}$ & $\begin{array}{l}\text { neu } \\
\text { ved. }\end{array}$ \\
\hline CMTF UP & 108 & 31 & 17 & 14 & 18 & 7 & 4 & 2 \\
\hline FE ZČU & $\begin{array}{l}114 \\
8\end{array}$ & 417 & 323 & 94 & 374 & 24 & 4 & 15 \\
\hline FTK UP & 571 & 109 & 45 & 64 & 81 & 16 & 4 & 8 \\
\hline FF UP & $\begin{array}{l}204 \\
5\end{array}$ & 698 & 465 & 233 & 216 & 189 & 257 & 36 \\
\hline JA Kroměříž & 247 & 23 & 11 & 12 & 14 & 8 & 0 & 1 \\
\hline PdF UP & $\begin{array}{l}200 \\
8\end{array}$ & 287 & 205 & 82 & 200 & 58 & 13 & 16 \\
\hline PdF UHK & 39 & 32 & 24 & 8 & 2 & 17 & 13 & 0 \\
\hline PF UP & 77 & 28 & 17 & 11 & 15 & 10 & 1 & 2 \\
\hline Celkem & $\begin{array}{ll}624 \\
3\end{array}$ & 5 & 710 & 518 & 920 & 329 & 296 & 80 \\
\hline
\end{tabular}

Tabulka 1 - Struktura výzkumného vzorku

Jak je $\mathrm{z}$ uvedené tabulky číslo 1 patrné, věková struktura výzkumného vzorku byla značně různorodá. Průměrný věk skupiny všech respondentů činil 32,4 roku, přičemž existovali rozdíly $\mathrm{v}$ průměrném věku na jednotlivých zapojených školách. Nejnižší věkový průměr 23,2 roku vykazovala Fakulta ekonomická Západočeské Univerzity v Plzni, nejvyšší věkový průměr 42,5 roku vykazovala Pedagogická fakulta Univerzity Hradec Králové. Tento fakt je možné vysvětlit tím, že některé školy využívají distanční složku vzdělávání spíše pro prezenční formu studia a některé spíše pro kombinovanou formu studia, kde je věk studentů zpravidla vyšší.

5 Průběh a výsledky realizovaného části výzkumného šetření zaměřené na identifikaci netypických skupin studentů

Jak naznačovaly výsledky výzkumů realizovaných na jiných vysokých školách
(Liška, Česal, 2008, s. 38), může existovat skupina studentů, která výukové aktivity v e-learningu odmítá, ale může existovat také významná skupina studentů, která naopak tyto aktivity vítá. Naším cílem bylo prokazatelně identifikovat tyto skupiny respondentů i v tomto výzkumném vzorku, popsat jejich vlastnosti a poprípadě korigovat negativní dopad některých skupin respondentů na výsledky výzkumného šetření. Dalším provedeným krokem při analýze získaných dat bylo použití shlukové analýzy, která by $\mathrm{v}$ tomto př́padě ale analyzovala shluky v množině respondentů, a zjistila tak, zda existují skupiny studentů, kteří evaluační kritéria hodnotí podobným způsobem. Tímto se respondenti rozdělili do skupin, které vykazovaly podobný způsob hodnocení kritérií. Výsledek této analýzy prezentuje uvedený třásňový graf číslo 1 


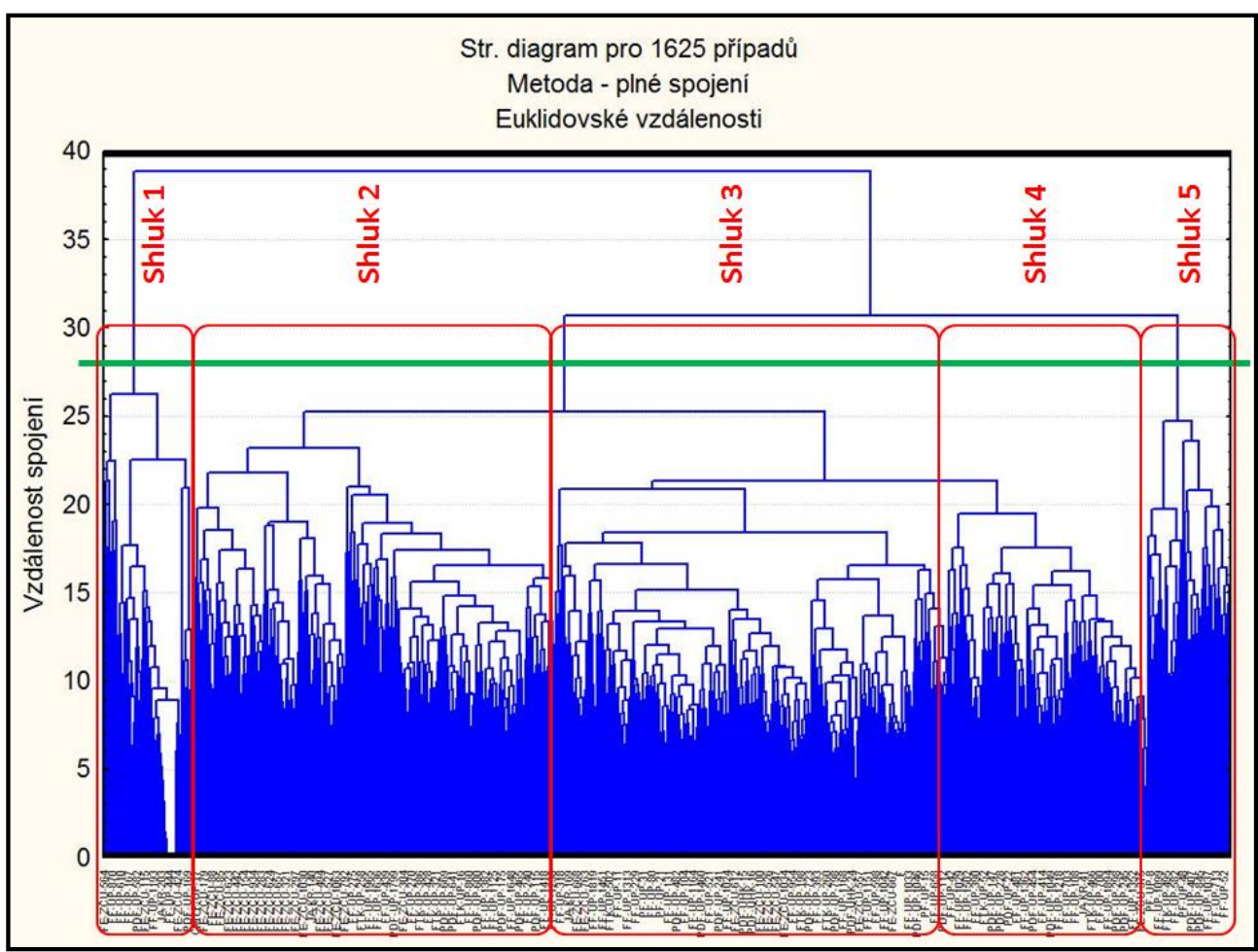

Graf 1 - Shluková analýza hodnoceni evaluačnich kritérii studenty

Z grafu číslo 1 je patrné, že studenty bylo možné rozdělit dle míry podobnosti hodnocení jednotlivých evaluačních kritérií do 3 samostatných skupin, a to dle vzdálenosti spojení na úrovni pohybující se okolo hodnoty 28. Jeden ze tř́ základních shluků se dále dělí na tři výrazné další shluky (v grafu označeny jako Shluk 2, Shluk 3 a Shluk 4), takže celkový počet samostatných shluků je roven pěti. Jedna skupina respondentů (označena jako Shluk 1) je naprosto odlišná od zbývajících 4 skupin respondenti̊, mezi nimiž existuje vyšší míra podobnosti hodnocení.

Zmíněná první skupina se tedy svým hodnocením zcela odlišovala, a bylo tedy možné předpokládat, že je to právě ta skupina studentů, kteří odmítají studium distanční vzdělávání formou e-learningu a tudíž projevují tendenci k negativnímu hodnocení a která výukové aktivity $\mathrm{v}$ e-learningu prokazatelně odmítala. Abychom s určitostí prokázali, že se jedná skutečně o skupinu studentů nespokojených s distančním vzděláváním formou e-learningu, použili jsme metodu k-průměrů (Kovařík, Kvapil, Vlach, 2006, s. 96), která měla za cíl jednoznačně danou skupinu identifikovat a popsat její charakteristiky. Z tohoto důvodu jsme provedli další shlukovou analýzu metodou k-průměrů, která rozdělila zkoumaný výzkumný vzorek na 5 skupin, jak ukazuje uvedený graf číslo 2. 


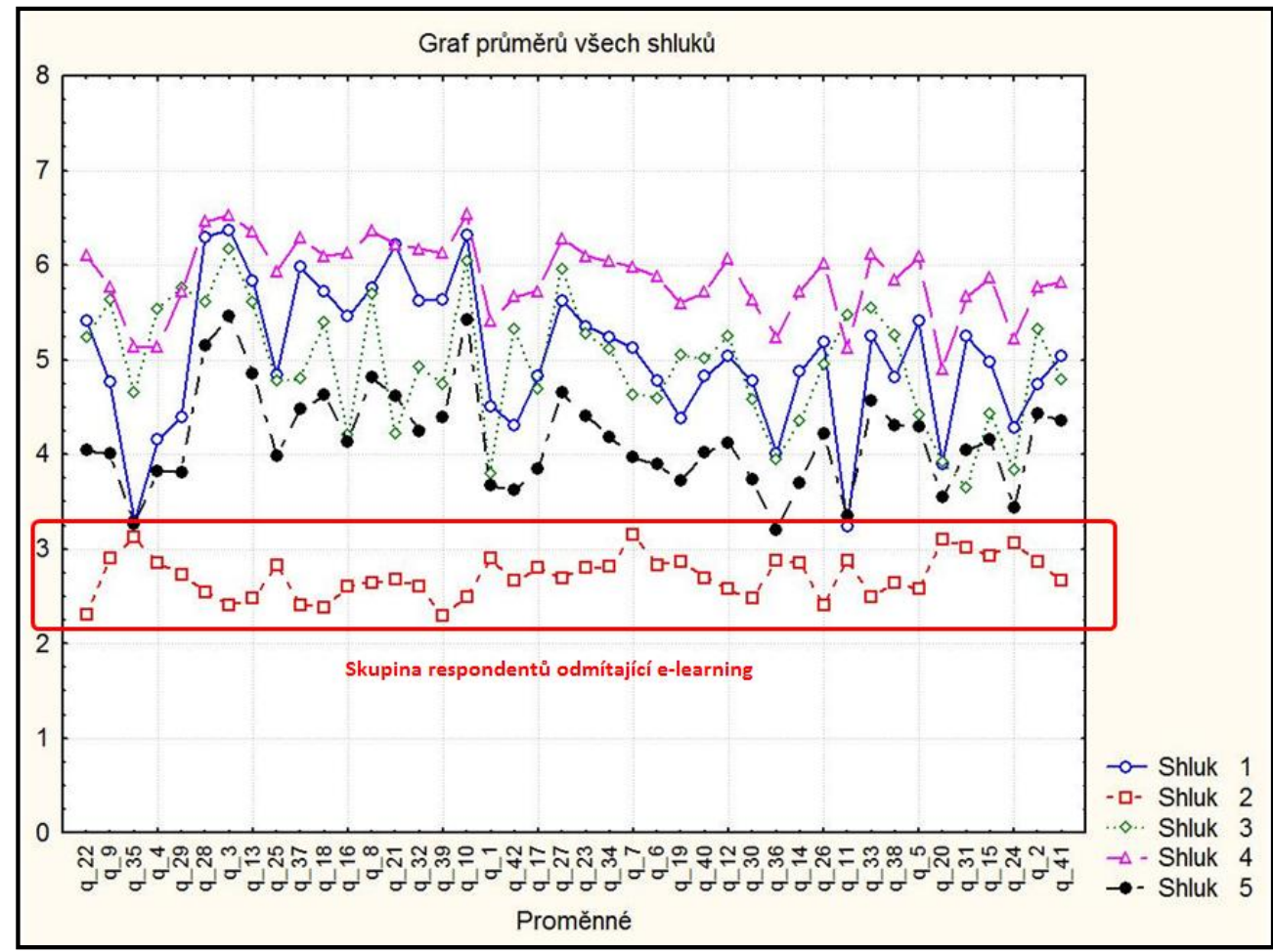

Graf 2 - Rozdělení respondentì do skupin dle podobnosti hodnocení kritérií

Na základě provedené analýzy bylo možné konstatovat, že výzkumný vzorek se při použití metody k-průměrů shlukuje do 5 charakteristických skupin respondenti̊. Bylo možné identifikovat skupinu respondentů, kteří odmítají e-learning (skupina je v grafu 2 označena jako Shluk 2), nebot' jejich hodnocení jednotlivých evaluačních kritérií je natolik nízké (hodnoty oscilují mezi bodem 2 a 3 na 7 stupňové hodnotící škále) a jeho rozptyl je tak malý, že toto tvrzení dokládají.

Pro úplnost celé provedené analýzy byly jednotlivé skupiny popsány a bylo určeno, kolik respondentů do té či oné skupiny patří. Přehled počtu respondenti̊ spadajících do 5 identifikovaných skupin uvádí tabulka 2.

\begin{tabular}{|c|c|c|c|c|c|c|}
\hline & \multicolumn{7}{c|}{ Respondenti n = 1625 } & Shluk 5 & Celkem \\
\cline { 2 - 7 } & Shluk 1 & Shluk 2 & Shluk 3 & Shluk 4 & Shluk & 1625 \\
\hline Počet & 519 & $\mathbf{5 9}$ & 373 & 343 & 331 & $\mathbf{1 0 0}$ \\
\hline $\begin{array}{c}\text { Podíl v } \\
\text { \% }\end{array}$ & 31,9 & $\mathbf{3 , 6}$ & 23,0 & 21,1 & 20,4 & \\
\hline
\end{tabular}

Tabulka 2 - Počty respondentů v jednotlivých skupinách dle podobnosti hodnocení kritérií

Jak je patrné $\mathrm{z}$ tabulky číslo 2, skupinu studentů, kteří odmítají e-learning, tvoří 59 studentů z celkového počtu 1625 respondentů, což je 3,6 \% respondentů a tento výsledek koresponduje s již dřive realizovaným výzkumný šetřením, ve kterém tuto skupinu tvořilo $4,2 \%$, $7,2 \%$ (Klement, 2011) a v př́padě výzkumných šetření na jiných vysokých školách pak 9,0\% (Liška, Česal, 2008, s. 38). Je možné s velkou jistotou říci, že nezávisle na třech samostatných výzkumných šetřeních existuje tato skupina, která může mít výrazný vliv na celkové výsledky celého výzkumného šetření.

\section{Závěry a diskuze}

Představa přirozeného využívání ICT, tedy i nástrojů e-learningu a LMS, dnešní generací studentů se bere jako fakt, který stojí na dvou hlavních argumentech. První z nich vychází z faktu, že dnešní dospívající či dokonce již malé děti manipulují a ovládají výpočetní techniku se zarážející samozrejmostí. Druhý argument vychází ze statistik užívání ICT podle věku, které ukazují, že na rozdíl od starších generací využívají skoro všichni dospívající Internet a mobilní telefon (Lupač, 2011). Na těchto dvou argumentech postavil $\mathrm{v}$ roce 1998 americký autor Don Tapscott (1998) své úvahy, kdy označil 
mocenský model rodiny za narušený, nebot' jsou to děti, které dnes učí rodiče orientovat se v digitálním prostředí. K jeho označení $N$-GEN a digitální generace se brzy přidali další: digitální domorodci (Prensky, 2001a), homo-zappiens (Veen, Vrakking, 2006), digitálně narození (Palfrey, Glasser, 2008) a další. „Digitálni domorodci jsou zvykli prijímat informace velmi rychle. Rádi dělají více činnosti zároveň (multitasking). Upřednostňuji zpracováni obrazového materiálu dř́ve než textu. Preferuji náhodný prístup kinformacím (hypertext) a nejlépe se jim pracuje v sitovém prostředi (on-line). Očekávají okamžitou pochvalu a časté oceňování vlastní tvorby (Prensky, 2001b). Prenskyho a Tapscottovy představy se staly velmi vlivnými a pokusilo je v postupu času podpořit či vyvrátit několik výzkumníků a to se střídavým úspěchem (Bennett, Maton, Kervin, 2008).

I když autor předložené studie není zastáncem ani odpůrcem myšlenky odlišného př́stupu ke vzdělávání „digitálních domorodcư“, tak zastává názor, že vzdělávání formou e-learningu, kdy je v co nejširší mířre použito ICT, může být vhodným prostorem pro ověření některých charakteristik generace digitálních domorodců. Uvedené postoje studentů českých vysokých škol na e-learning mohou tedy pomoci s identifikací či stanovením rozsahu príípadné skupiny studentů, kteří disponují digitálním myšlením (digital wisdom; Prensky, 2009). Hlavní charakteristikou skupiny digitálních domorodců je skutečnost, že „preferují náhodný prístup $k$ informacím (hypertext) a nejlépe se jim pracuje v sitovém prostředi (on-line)" (Prensky, 2001a). Dle zjištěných výsledků existuje skupina studentů, která prokazatelně odmítá studium formou e-learningu, i když je realizována za využití hypertextových vzdělávacích materiálů a on-line prostředí. V této skupině se prokazatelně vyskytují jak studenti narození po roce 1990, tak studenti narození to tomto roce a tudíž spadající do předpokládané skupiny digitálních domorodců. I když může být tato skutečnost zaprríčiněna mnoha dalšími faktory, nabízí se otázka, zda skutečně generace studentů narozená po roce 1990 (toto odpovídá plošnému zavádění ICT v podmínkách České republiky) preferuje pouze on-line vzdělávací aktivity.

\section{Literatura}

BATES, A., POOLE, G. Effective Teaching with Technology in Higher Education. 1. ed., San Francisco: Jossey-Bass/John Wiley, 2003. 117 p. BENNETT, S,. MATON, K., \& KERVIN, L. The 'digital natives' debate: A critical review of the evidence. In: British Journal of Educational Technology 39(5), 2008. pp. 134-145.

HORÁK, F., CHRÁSKA, M. Metodologie pedagogiky. 1. vyd., Olomouc: Vydavatelství Univerzity Palackého, 1983. 147 s.

JEŽEK, S., VACULÍK M., WORTNER, V. Základní pojmy zmetodologie psychologie: definice a vysvětlení [online]. [vid. 6. února 2011]. Dostupné z: http://is.muni.cz/do/1499/el/estud/fss/ps06/psy11 2/Vaculik_M._Jezek_S._Wortner_V._200 6___Zakladni_pojmy_z_metodologie.pdf.

KLEMENT, M. Prístupy $\mathrm{k}$ hodnocení elektronických studijních opor určených pro realizaci výuky formou e-learningu. 1. vyd., Olomouc: Velfel, 2011, 124 s. ISBN 978-8087557-13-6.

KOPECKÝ, K. E-learning (nejen) pro pedagogy. 1. vyd., Olomouc: Hanex, 2006. 121 s. ISBN 8085783-50-9.

KOSCHIN, F. Statgraphics aneb statistika pro každého. 1. vyd., Praha: Grada, 1992. 360 s. ISBN 80-85424-70-3.

KOVAŘÍK, Z., KVAPIL, J., VLACH, P. Úvod do počitačové analýzy vícerozměrných úloh z policejní praxe. 1. vyd., Praha: vydavatelství PA ČR, 2006. 206 s. ISBN 80-7251-228-5.

LIŠKA, V., ČESAL, J. Postoje studentů vysokých škol k E-learningu. 1. vyd., Praha: vydavatelství ČVUT, 2008. 64 s. ISBN 978-80-01-04214-4.

LOWENTHAL, P. R., WILSON, B. A description and typology of the online learning landscape. In: M. Simonson (Ed.), 32nd Annual proceedings: Selected research and development papers presented at the annual convention of the Association for Educational Communications and Technology[online]. Washington D. C.: Association for Educational Communications and Technology, 23. zárí 2009. [vid. 14. března 2011]. Dostupné z: http://www.patricklowenthal.com/publications/A ECT2009TypologyOnlineLearning.pdf.

LUPAČ, P. Mýty (a realita) digitální generace, 2011, [online]. [vid. 6. února 2011]. Dostupné z: http://www.lupa.cz/clanky/myty-a-realitadigitalni-generace/

MAUTHE, A., THOMAS, P. Professional Content Management Systems: Handling Digital 
Media Assets. 1. ed., John Wiley \& Sons, 2004. $234 \mathrm{p}$.

PALFREY, J., GLASSER, U. Born Digital: Understanding the First Generation of Digital Natives. Basic Books, 2008. 175 p.

PAULSEN, M. F. Online Education and Learning Management Systems - Global Elearning in a Scandinavian Perspective. 1. ed., Oslo: NKI Forlaget, 2003. 219 p.

PRENSKY, M. (2009) H. Sapiens Digital: From Digital Immigrants and Digital Natives to Digital Wisdom, [online]. [vid. 12. prosince 2012]. In: Innovate. Dostupné $\mathrm{z}:$ http://www.innovateonline.info/pdf/vol5_issue3/ H._Sapiens_Digital-

__From_Digital_Immigrants_and_Digital_Native s_to_Digital_Wisdom.pdf

PRENSKY, M. Digital Natives, Digital Immigrants, 2001, [online]. [vid. 6. února 2009]. In: On the Horizon 9(5), 1-6. Dostupné z: http://www.marcprensky.com/writing/Prensky\%2 $0-$

\%20Digital\%20Natives, \%20Digital\%20Immigra nts\%20-\%20Part1.pdf

PRENSKY, M. Digital Natives, Digital Immigrants: Do They Really Think Differently? [online]. [vid. 22. řijna 2006]. In: On the Horizon 9(5), 7-11. Dostupné z: http://www.marcprensky.com/writing/Prensky\%2 0 -

\%20Digital\%20Natives, \%20Digital\%20Immigra nts\%20-\%20Part2.pdf

PRŮCHA, J. Pedagogická encyklopedie. 1. vyd., Praha: Portál, 2009. 936 s. ISBN 978-80-7367546-2.
ŘEZANKOVÁ, H. Analýza dat z dotazníkových šetřeni. 2. vyd., Praha: Professional Publishing, 2010. 217 s. ISBN: 978-80-7431-019-5.

ŠEDÁ, J. Elearning - tvorba studijnich opor [online]. VŠE Praha: Integrovaný informační systém, 12. srpna 2010. [vid. 1. dubna 2011]. Dostupné

http://isis.vse.cz/dok_server/slozka.pl?id=51;dow nload $=81$.

TAPSCOTT, D. Growing Up Digital: The Rise of the Net Generation. 1. ed., New York: McGrawHill, 1998. 342 p.

VEEN, W., VRAKKING, B. Homo Zappiens. Growing Up In A Digital Age. 1. ed., Network Continnum Education, 2006. 34 p.

ZOUNEK, J. E-learning - jedna z podob učeni v moderni společnosti. 1. vyd., Brno: Masarykova univerzita, 2009. 161 s. ISBN 978-80-210-51232.

Př́ispěvek vznikl za podpory GAČR v rámci řešení projektu č. P407/11/1306

„Evaluace vzdělávacích materiálů určených pro distanční vzdělávání a e-learning“

PhDr. Milan Klement Ph.D., Doc. PhDr. Miroslav Chráska Ph.D.

Katedra technické a informační výchovy

Pedagogická fakulta UP

Žižkovo nám. 5

77140 Olomouc, ČR

Tel: +420 585635811, +420 585635803

E-mail: milan.klement@ upol.cz,

miroslav.chraska@upol.cz

Www pracoviště: www.kteiv.upol. 